\title{
The Common Types of Pollen Grains Collected by Honey Bee Workers Apis Mellifera, L. (Hymenoptera:Apidae) in El-Sabheia Region, Alexandria Governorate, Egypt
}

Hassan A. A. Mesbah ${ }^{1}$, Nagda A. A. El-Sayed ${ }^{1}$, Nadia K. Hassona ${ }^{1}$, Khaled M. A. Abdel-Hameed ${ }^{2}$ and

\author{
Hala A. S. Abdel- Sattar ${ }^{2}$
}

\begin{abstract}
pollen grains are major source of protein, fats, vitamins and minerals. It is essential for the growth of larvae and young adult bees. Collecting pollen depend on many factors such as race of honey bee, honey bee health, environmental conditions and planting area around the apiaries. The present study is concerned with the effect of pollen grains type, effect of using pollen trap on honey produce, brood production and trapped pollen. The obtained results showed that the highest amount of trapped pollen was in August and summer season, while the lowest amount was in May and spring season, also in September there were the highest mean areas of sealed brood and honey at the colonies of traps and without trap while the lowest mean was in May in colonies with traps and without traps. Also results revealed that there were 5 different floral sources were Phragmites ustralis, Eucalyptus, Calistemon visiminalis, Schinus terebinthifolius and Trifolium alexandrinum. Chemical analysis of the trapped pollen grains showed that pollen of Calistemon viminalis recorded the highest level of moisture, crude protein, ash and crude lipids, while Eucalyptus pollen grains recorded the highest amount of reducing sugar and the lowest amount of crude protein
\end{abstract}

Keywords: Honey bee, Apis mellifera, pollen grains, pollen traps, brood, chemical analysis.

\section{INTRODUCTION}

Honey bee Apis mellifera L. colony need pollen and nectar to fuel foraging flights, generate heat to thermo regulate the nest and to rear brood. Nectar is a carbohydrate source, while pollen grains are the male germs of flowers, rich in high quality protein, which serve as the building material for growth and tissue repair to honey bee colonies (Somerville, 2000; AlGhamdi, 2002; Mishima et al., 2005). The demand for pollen increases during times of heavy wax production and honey flow (Somerville, 2000).

Bee worker's start to consume pollen just a few hours after emerging and this amount reaches a maximum when they are four to nine days old (Crailshem et al., 1992).

Pollen supplies the bees with the protein, lipids, vitamins and minerals needed to rear larvae (De Groot,
1953; Manning, 2001). The quantity of pollen affects the number of eggs that laid by the queen and proportion that are reared to adults (Allen and Jeffree, 1956; Doull 1973; Hellmich and Rothenbuhler, 1986).

Honey bee collect a large quantity of pollen from different crop over the year, but pollen gathering activity depend on some factors such as race of honey bee, honey bee health, environmental conditions and planting area around the honey bee colonies, ....... etc.

The honey bee workers collect different types of pollen irrespective of their protein content but it may be depend on other factors such as volatile component, colony status and color. The plant source of pollen can often identified from the color of the pollen loads and almost $0.01 \%$ of all pollen loads are color mixed [Stanley and Linskens, 1974; C.F.(Hassan et al., 2015)].

The amount of pollen and brood in the colony reflects its status and can be used to expect the honey yield produced at the end of the season. Several investigators have proved positive correlation between stored pollen, brood production and honey yield, (Shoreirt et al., 2002; Jevtic et al. , 2009) .

The collection of pollen by bee workers was influenced by numerous factors including both internal and external ones. Internal factors like the higher area under brood in the colony, which stimulate the bee workers to collect more pollen. The external factors are temperature, light, wind and rain ( Kaur and Kumar, 2013).

The aim of the present work could be summarized as follow:

1.Study the effect of environmental conditions on the amount of pollen grains type.

2.Study the effect of pollen trap on honey, brood production and pollen

3.Chemical analysis of some collected pollen grains, which affect the brood rearing. 


\section{MATERIALS AND METHODS}

The present study was carried out in an apiary situated in the experimental farm of El-sabheia research station, Alexandria city.

\section{Honeybee colonies}

Honey bee hybrid Carniola local strain queens were exploited, where eight honey bee colonies equal in their strength; headed by new mated queens.

\section{Pollen grains collection}

Pollen grains were collected by using a trap of pollen grain placed in the front of each of the eight colonies entrance, throughout three sequenced days; from Sunday up to Tuesday of each week.

Pollen samples were collected; and weighted by a sensitive analytical balance; in order to weight the amount of collected pollen in grams ( $\mathrm{g}$ ) through 3 days / colony / week during the period of work (2016).

\section{Description of pollen trap used}

Pollen pellets were removed from the foraging bee workers before they enter the hive by using a pollen trap. The used pollen trap was a wooden box. The fallen pollen loads, through a horizontal wire gauze screen into a collecting tray were removed as required. Collecting efficiency was determined by recording 100 bee worker's in each hive entering with pollen loads through an empty trap. Number of pellets fallen in the tray was counted and the efficiency was calculated according to the equation reported by Khattab( 1976), El-Shakaa (1977) and Ewies et al. (1980) as follows:

Trap efficiency $=$ (number of pollen pellets in the box $/ 200) \times 100$. Efficiency was found to be $35 \%$

\section{Examination of pollen grains}

Samples of removed pollen grains from pollen trap were collected. Each sample was placed on a slide and freed from fat with drop of ether. A drop of stained glycerin jelly melted in a bath water was put on a cover slide, and this was placed over the layer of pollen. The finished preparation was sealed with dilute solution of canda balsam and preceeded for examination by light microscope. Pollen identification was based on relevant literature (Shokry, 1959) and the collection of reference pollen slides from local flora which gave brief descriptions of the observed pollen in the samples.

\section{Chemical analysis of the trapped and stored pollen}

Yield of the trapped pollen was daily collected as mixture of different pollen types and stored in clean vials under freezing temperature $(-18 \square \mathrm{C})$ until further procedures. The collected pollen was through separated to different groups and classified according to its color. Three samples $(5 \mathrm{~g}$ ) of each identified pollen group represented a particular pollen type. The collected samples were subjected to chemical analysis for determination of their chemical components. Chemical analysis of the trapped pollen was carried out in laboratory of Faculty of Agriculture (Saba Basha), Alexandria University for determining the following contents:-

A- Moisture: It was determined by drying the pollen sample to constant weight in an air oven at 70 ?C, then the percentage of moisture content was estimated. (Bell et al., 1983).

B- Crud protein: Crude protein content was determined, in duplicate, according to Domas methods (A.O.A.C, 2000). Total nitrogen content was determined using an elemental analysis, Calibrated against standards. Pollen samples $(0.2 \mathrm{~g})$ were weighted into a combustion boat, and combusted at $950^{\circ} \mathrm{C}$; to determine total crude protein, nitrogen values were multiplied by a conversion factor of 6.25 (Roulston et al., 2000)

C- Crud Lipids Lipids content of the pollen samples were measured gravimetrically after extraction with petroleum ether through using a Soxilts lipids extraction apparatus. (Bell et al., 1983).

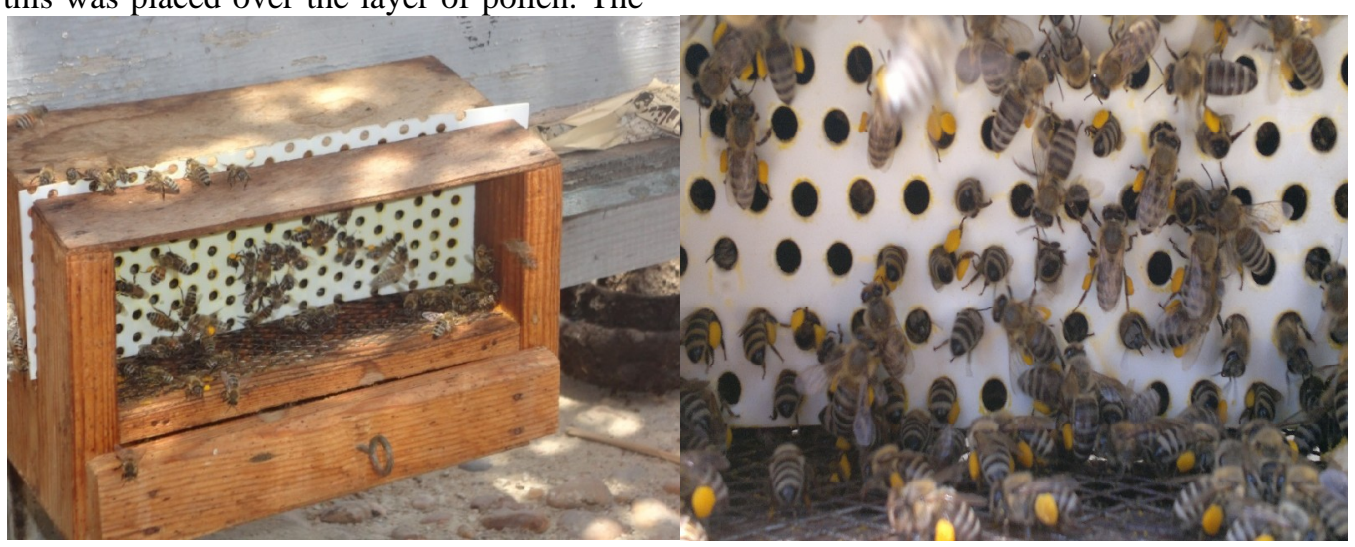

The trap of pollen grains 
D- Ash content: It was measured through heating pollen samples in a muffle furnace at 600 ? until a uniform gray-white ash remained. The samples were then weighted for estimation the average percentage of the ash content. (Bell et al., 1983).

E- Reducing sugar The content of the reducing sugars was determined according to the method reported by Gordon and Diane (2002).

\section{Evaluation of sealed brood and egg laying / queen during the experimental periods}

In seasons of 2016 Sealed brood was measured by using the inch square method the appraisal was done by using a typical langstroth frame, which is sub-divided into square inches by means of wire (Al-Trikrity et al. , 1971; Hassona, 2006) . Each sealed brood frame was taken from each colony. After removing the bees and putting the square inch frame on it, the cells of the sealed brood were counted and quantified. The counts of worker brood were done at 12 days intervals.

\section{Evaluation of honey yield}

The honey stored in cells of the wax frame that has been measured by subdivided langstroth frame in square inches was calculated and the area of stored honey by workers in the eight colonies was compared with control colonies.

\section{Statistical analysis}

Data of the present investigation were subjected to the analysis of variance (ANOVA) using "F Test" following the randomized complete block design (RCBD), with three replicates for each treatment. The least significant differences (L.S.D) at the 0.05 probability level were determined according to computer program (COSTAT software, 1988) and Duncan's Multiple Range Testes modified by Steel and Torrie (1981) to compare the average numbers of the inspected insect at different intervals.

\section{RERSULTS AND DISCUSSION}

\section{Monthly average of trapped pollen}

Data in Table (1) and Figure (1) showed that the highest amount of trapped pollen was recorded in August (106.19 g/colony) followed by that amount collected in September (79.22 g / colony), when the average of temperature and relative humidity were $31.25 \mathrm{C}^{\circ}, \quad 59.5 \%$ and $30.75^{\circ} \mathrm{C}, 55 \%$, respectively. However, the lowest amount of trapped pollen was recorded in May $\left(29.51 \mathrm{~g} /\right.$ colony) at $30^{\circ} \mathrm{C}$ and $51.50 \%$ R.H.

Table 1. Monthly average of the trapped pollen (g/colony)

\begin{tabular}{|c|c|c|c|}
\hline Month & $\begin{array}{c}\text { Avg. of } \\
\text { trapped } \\
\text { pollen (g/ } \\
\text { colony) }\end{array}$ & $\begin{array}{l}\text { Avg. of the } \\
\text { Max. } \\
\text { Temp. }\left(\mathbf{C}^{\circ}\right)\end{array}$ & $\begin{array}{c}\text { Avg. of } \\
\text { the } \\
\text { relative } \\
\text { Hum.\% }\end{array}$ \\
\hline May & $29.51^{\mathrm{c}}$ & $30.00^{\mathrm{ab}}$ & $51.50^{\mathrm{b}}$ \\
\hline June & $41.98^{\mathrm{c}}$ & $31.00^{\mathrm{a}}$ & $59.25^{\mathrm{a}}$ \\
\hline July & $39.50^{c}$ & $31.00^{\mathrm{a}}$ & $60.25^{\mathrm{a}}$ \\
\hline Aug & $106.19^{\mathrm{a}}$ & $31.25^{\mathrm{a}}$ & $59.50^{\mathrm{a}}$ \\
\hline Sep & $79.22^{\mathrm{b}}$ & $30.75^{\mathrm{a}}$ & $55.00^{\mathrm{ab}}$ \\
\hline Oct & $40.36^{\mathrm{c}}$ & $27.75^{\mathrm{b}}$ & $57.75^{\mathrm{a}}$ \\
\hline Total & 336.76 & 181.75 & 343.25 \\
\hline Mean & $\begin{array}{c}56.13 \pm \\
27.30\end{array}$ & $\begin{array}{c}30.29 \pm \\
1.20\end{array}$ & $\begin{array}{c}57.21 \pm \\
3.07\end{array}$ \\
\hline L.S.D 0.05 & 26.19 & 2.27 & 5.45 \\
\hline
\end{tabular}

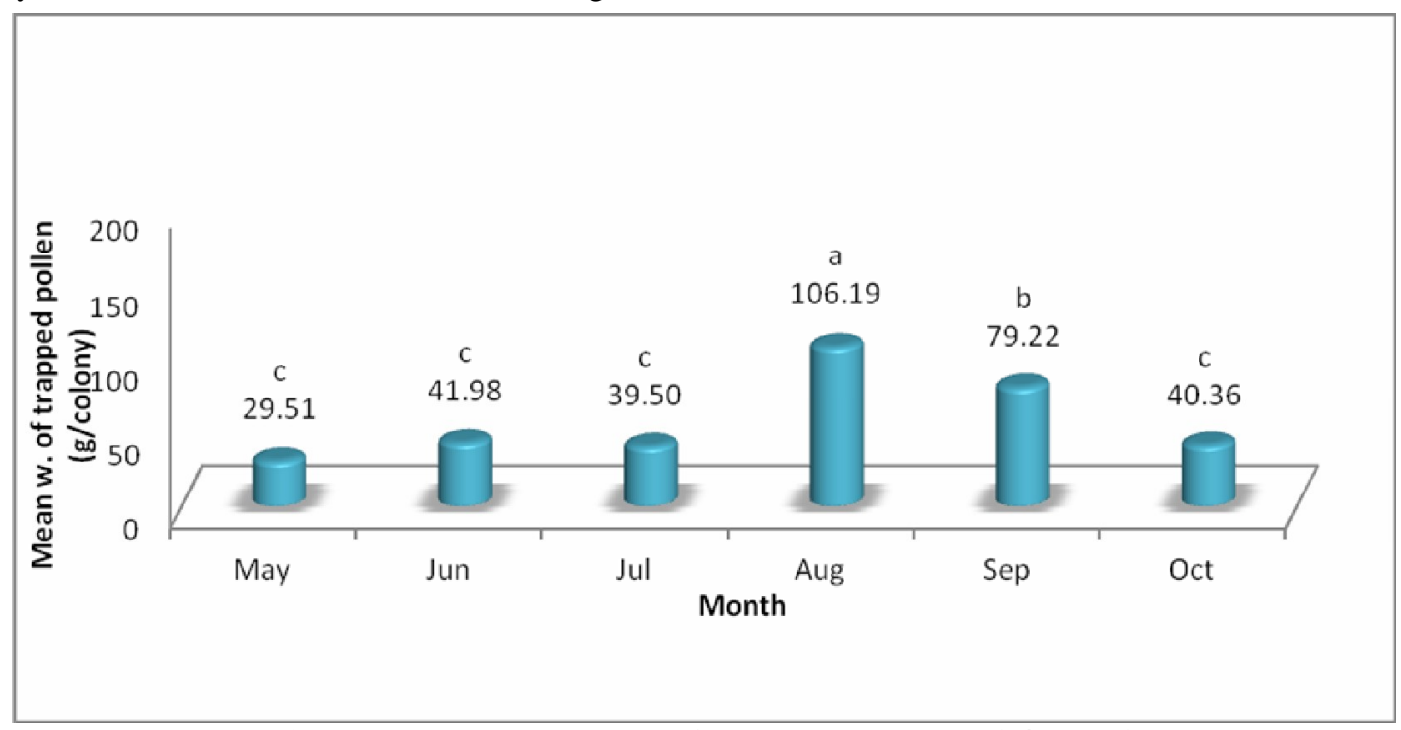

Figure 1. Monthly average of the trapped pollen (g/colony) 
The obtained results revealed that the experimental colonies collected more quantity of pollen (106.19 g/colony) in August and this amount was as three times as that collected in May(29.51 g/colony). The obtained results may close to those results reported by Hassan et al. (2015) who found that the highest amount of trapped pollen were recorded in August, when temperature was $35^{\circ} \mathrm{C}$ and relative humidity was $52 \%$, however the lowest amount was recorded in April at temperature of $25.42^{\circ} \mathrm{C}$ and $51 \%$ R.H.

\section{Seasonal average amount of collected pollen}

Data presented in Table (2) and Figure (2) showed the collection amount of pollen at different seasons during 2016.The highest amount of collected pollen was recorded in summer season ( $240.47 \mathrm{~g} /$ colony) while, the lowest amount was recorded in spring season $(43.88 \mathrm{~g} /$ colony). That is might be due to increasing of temperature in summer than spring and autumn season, and increasing the flora in this time. These results are agree with Ismail et al. (2013) who found that the mean amount of trapped pollen was $588.72 \mathrm{~g} /$ colony/season), with detection of high peaks in summer and spring .

\section{The mean areas of sealed brood ,pollen and honey production (inch ${ }^{2}$ )}

As shown in the Table (3)and Figure (3) the results revealed that the highest mean areas of sealed brood of $1398.25,1262.25,1224.00$ and 1130.50 inch $^{2}$ were recorded in September, July, June and August, in respect with a total mean area of $1099.33 \mathrm{inch}^{2}$.

On the other hand the lowest mean areas of sealed brood of 760.5 and 820.25 inch $^{2}$ were obtained in October and May. There were no significant differences among the mean of sealed brood area during the chosen months of 2016. The untreated (control colonies without any grain traps) showed that there is an increase of mean area of sealed brood (1496.00, 1405.33, 1280.67 and 1246.67inch ${ }^{2}$ ) in September, June, July and August, in respect. The lowest mean area of the control colony was recorded in May (974.67 $\mathrm{inch}^{2}$ ).

In concern to honey production, Table (3) show the produced honey $\left(\right.$ inch $\left.^{2}\right) / 8$ colonies throught the season of 2016. It could be concluded that in September the obtained honey yield was 2346.00 and 2697.33 inch $^{2}$ in treatment of pollen traps and control, in sequenthly followed by that yield recorded in October (1844.00 and 2300.67 inch $^{2}$ with trap and without trapped colonies with the total mean of 1564.71 and $1873.78 \mathrm{inch}^{2}$, respectively).

However, the lowest mean area of honey yield was recorded in May for both treatment and control (675.75 and 702.67 inch $^{2}$, in respect). Results indicated that there were no significant differences between trapped and control colonies. The highest honey yield was obtained in September followed by that yield of October and the lowest honey yield was correspondingly recorded in May. Honey yield increased in autumn (September, October and November) due to the activity of worker bees in autumn for collecting the nectar than the other seasons.

Table 2. Seasonal average amount of pollen collection (g/colony)

\begin{tabular}{cc} 
Seasons & $\begin{array}{c}\text { Mean amount of collected pollen } \\
(\text { g/colony) }\end{array}$ \\
\hline Spring & $43.88^{\mathrm{b}}$ \\
Summer & $240.47^{\mathrm{a}}$ \\
Autumn & $52.41^{\mathrm{b}}$ \\
Total & 336.76 \\
Mean & $112.25 \pm 90.73$ \\
L.S.D $\mathrm{D}_{0.05}$ & 53.84 \\
\hline
\end{tabular}

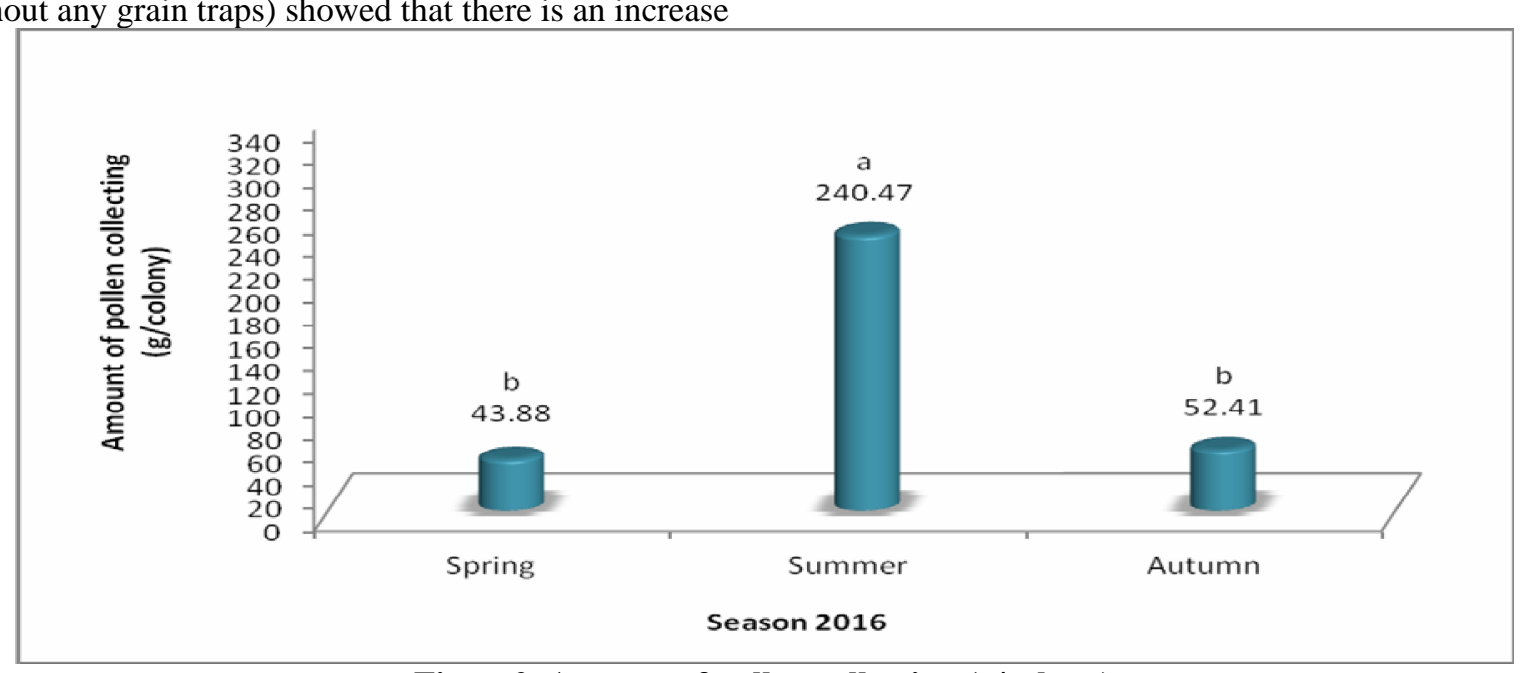

Figure2. Amount of pollen collecting (g/colony) 
Table 3. The mean areas of sealed brood, pollen and honey (inch ${ }^{2}$ ) for 8 tested colonies during 2016

\begin{tabular}{|c|c|c|c|c|c|c|}
\hline \multirow{3}{*}{ Monthes } & \multicolumn{6}{|c|}{ Mean area $\left(\right.$ inch $\left.^{2}\right)$} \\
\hline & \multicolumn{2}{|c|}{ Sealed brood } & \multicolumn{2}{|c|}{ Honey } & \multicolumn{2}{|c|}{ Pollen } \\
\hline & Trapped & Control $^{*}$ & Trapped & Control & Trapped & Control \\
\hline May & $820.25^{\mathrm{b}}$ & $974.67^{\mathrm{b}}$ & $675.75^{\mathrm{c}}$ & $702.67^{b}$ & $150.50^{\mathrm{b}}$ & 198.33 \\
\hline June & $1224.00^{\mathrm{a}}$ & $1405.33^{\mathrm{a}}$ & $1385.50^{\mathrm{b}}$ & $1677.33^{\mathrm{ab}}$ & $205.63^{\mathrm{ab}}$ & 351.33 \\
\hline July & $1262.25^{\mathrm{a}}$ & $1280.67^{\mathrm{ab}}$ & $1606.50^{\mathrm{b}}$ & $1836.00^{\mathrm{ab}}$ & $176.38^{\mathrm{b}}$ & 284.67 \\
\hline Aug & $1130.50^{\mathrm{a}}$ & $1246.67^{\mathrm{ab}}$ & $1530.00^{\mathrm{b}}$ & $2028.67^{\mathrm{a}}$ & $301.00^{\mathrm{a}}$ & 408.00 \\
\hline Sep & $1398.25^{\mathrm{a}}$ & $1496.00^{\mathrm{a}}$ & $2346.00^{\mathrm{a}}$ & $2697.33^{\mathrm{a}}$ & $189.56^{\mathrm{ab}}$ & 364.00 \\
\hline Oct & $760.75^{\mathrm{b}}$ & $1099.33^{\mathrm{ab}}$ & $1844.50^{\mathrm{ab}}$ & $2300.67^{a}$ & $158.03^{\mathrm{b}}$ & 249.33 \\
\hline Total & 6596.00 & 7502.67 & 9388.25 & 11242.67 & 1181.09 & 1855.67 \\
\hline Mean & $\begin{array}{c}1099.33 \pm \\
232.71\end{array}$ & $\begin{array}{c}1250.44 \pm \\
175.17\end{array}$ & $\begin{array}{c}1564.71 \pm \\
502.33\end{array}$ & $\begin{array}{c}1873.78 \pm \\
618.60\end{array}$ & $\begin{array}{c}196.85 \pm \\
50.09\end{array}$ & $\begin{array}{c}309.28 \pm \\
71.90\end{array}$ \\
\hline L.S.D 0.05 & 289.34 & 416.42 & 543.77 & 1217.86 & 117.00 & N.S ${ }^{* * *}$ \\
\hline
\end{tabular}

*Control = colony without trapped pollen

** N.S $=$ Not significant

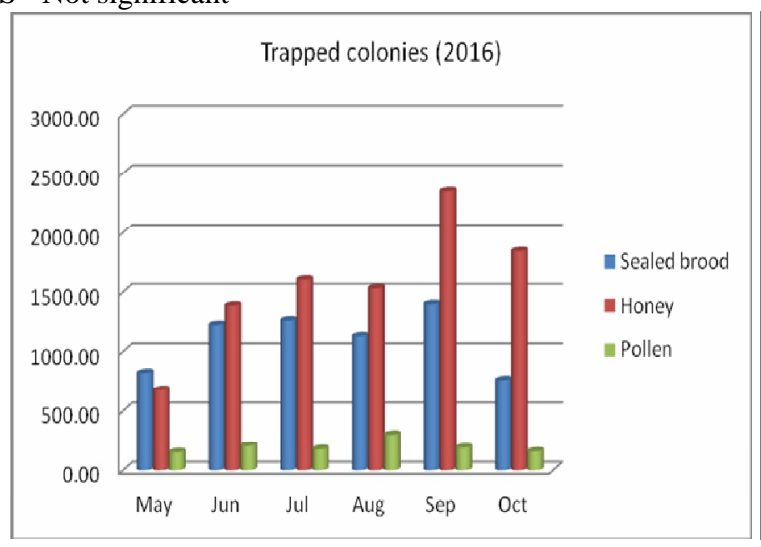

(a)

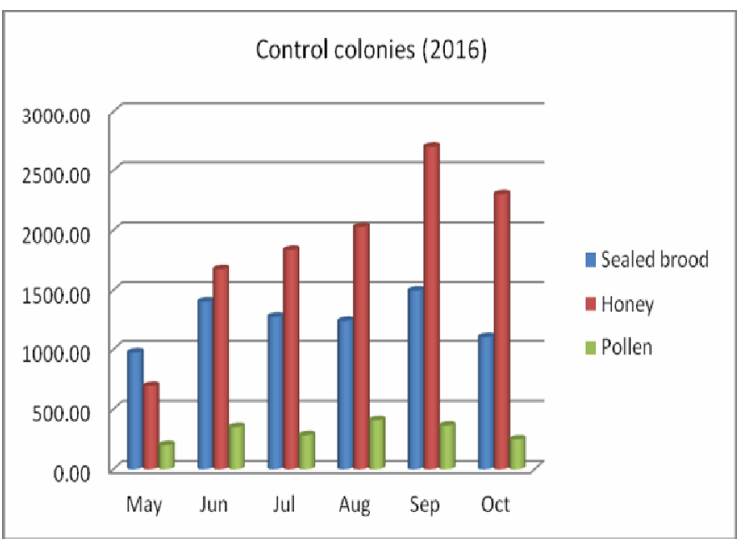

(b)

Figure 3. The mean areas of sealed brood, pollen and honey (inch ${ }^{2}$ ) for 8 tested colonies during 2016 (a. Trapped colonies) (b. Not trapped colonies)

In the year of 2016, the mean area of pollen grains collected/ colony/ month was determined during the periods of May to October. Results in Table (3) also revealed that the highest mean area of trapped pollen grains as compared with control (without trap) was recorded in August (301.00 and $408.00 \mathrm{inch}^{2}$, respectively) followed by that pollen area of 205.63 and 351.33 inch $^{2}$ that recorded in June inrespect. The lowest mean area of the trapped pollen grains and control were recorded in May (150.50 and $198.33 \mathrm{inch}^{2}$, in respect). In general, the obtained results revealed that colonies collected more quantity of pollen (301.00 and 408 inch $^{2}$ ) at the colonies used trapped pollen and without trap, respectively in August which reflected on high production of sealed brood and honey.

These results are not close to those results reported by Bobrzecki and Wilde (1991) who found that the brood area was reduced in colonies fitted with board traps. Pollen trapping did not lower the amount of produced honey.

\section{Identification and classification of the trapped pollen}

Identification of different floral sources of the collected pollen showed that there were 5 different floral sources available in the areas of study(Table 4). It was found that common reed( Phragmites ustralis) presented by the highest percentage $(47.31 \%)$ in Summer and Autumn seasons, followed by Eucalyptus and glass brush (Calistemon visiminalis) with percentages of $18.19 \%$ and $16.48 \%$, respectively, which present in Spring, Winter and Autumn, while the lowest percentage was belonging to clover (Trifolium alexandrinum) (7.73\%) which present in Spring only, followed by Brazilian papper (Schinus terebinthifolius) $(10.29 \%)$ 
Table 4. Percentages of some collected pollen and quantity in different seasons (g/ 8 colonies)

\begin{tabular}{|c|c|c|c|c|c|c|c|c|c|}
\hline \multirow[b]{2}{*}{$\begin{array}{l}\text { Common } \\
\text { name }\end{array}$} & \multirow[b]{2}{*}{ Family } & \multirow[b]{2}{*}{ Scientific name } & \multirow[b]{2}{*}{$\begin{array}{l}\text { Precence } \\
\text { in traps }\end{array}$} & \multicolumn{4}{|c|}{ Quantity of pollen /g } & \multirow[b]{2}{*}{ Total } & \multirow{2}{*}{$\begin{array}{c}\text { Percentage } \\
\text { of collected } \\
\text { pollen \% }\end{array}$} \\
\hline & & & & Spring & Summer & Vinter & $\begin{array}{c}\text { Autum } \\
\text { n }\end{array}$ & & \\
\hline $\begin{array}{l}\text { Glass } \\
\text { brush }\end{array}$ & Myrtaceae & $\begin{array}{l}\text { Calistemon } \\
\text { visiminalis }\end{array}$ & $*$ & 58.72 & 0.00 & 6.53 & 109.14 & 174.39 & 16.48 \\
\hline $\begin{array}{c}\text { Eucalyptu } \\
\text { S }\end{array}$ & Myrtaceae & Eucalyptus sp & $* *$ & 104.36 & 0.00 & 9.18 & 78.89 & 192.43 & 18.19 \\
\hline Clover & Fabaceae & $\begin{array}{c}\text { Trifolium } \\
\text { alexandrinum }\end{array}$ & $\begin{array}{l}\text { From } 12 \\
\text { Apr to } 7 \\
\text { Jun }\end{array}$ & 81.74 & 0.00 & 0.00 & 0.00 & 81.74 & 7.73 \\
\hline $\begin{array}{l}\text { common } \\
\text { reed }\end{array}$ & Poaceae & $\begin{array}{c}\text { Phragmites } \\
\text { ustralis }\end{array}$ & $\begin{array}{l}\text { From } 14 \\
\text { Aug to } \\
20 \text { Sep } \\
\& 6 \text { to } 15 \\
\text { Nov }\end{array}$ & 0.00 & 488.65 & 0.00 & 11.90 & 500.55 & 47.31 \\
\hline \multirow[t]{2}{*}{$\begin{array}{l}\text { Brazilian } \\
\text { papper }\end{array}$} & nacardiaceae & $\begin{array}{c}\text { Schinus } \\
\text { terebinthifolius }\end{array}$ & $\begin{array}{l}\text { From } 18 \\
\text { Sep to } 11 \\
\text { Oct }\end{array}$ & 0.00 & 25.85 & 0.00 & 83.00 & 108.85 & 10.29 \\
\hline & & & & \multicolumn{4}{|c|}{ Total } & 057.96 & $100 \%$ \\
\hline
\end{tabular}

* From 1 Jan to 14 Feb , 6 Mar to 24 Apr, 5 Jun to 21 Jun and 2 Oct to 11 Dec .

**From 1 Jan to 8 Mar, 12 Apr to 21 Jun and 23 Oct to 13 Dec.

Table 5. Chemical analysis of some trapped pollen

Plant percentage of chemical componant \%

\begin{tabular}{ccccccc}
\hline common name & scientific name & Moisture & $\begin{array}{c}\text { crude } \\
\text { lipids }\end{array}$ & $\begin{array}{c}\text { crude } \\
\text { protein }\end{array}$ & $\begin{array}{c}\text { Ash } \\
\text { content }\end{array}$ & $\begin{array}{c}\text { Reducing } \\
\text { sugar }\end{array}$ \\
\hline Glass brush & Calistemon viminalis & $16.39^{\mathrm{a}}$ & $4.31^{\mathrm{a}}$ & $21.70^{\mathrm{a}}$ & $4.40^{\mathrm{a}}$ & 1.86 \\
Clover & Trifolium alexandrinum & $13.66^{\mathrm{b}}$ & $1.71^{\mathrm{b}}$ & $15.68^{\mathrm{b}}$ & $3.11^{\mathrm{b}}$ & 1.96 \\
$\begin{array}{c}\text { Eucalyptus } \\
\text { Common Reed }\end{array}$ & $\begin{array}{c}\text { Phragmites australis } \\
\text { Brazilian }\end{array}$ & $14.38^{\mathrm{a}}$ & $1.86^{\mathrm{b}}$ & $9.70^{\mathrm{c}}$ & $1.59^{\mathrm{c}}$ & 2.28 \\
pepper & Schinus terebinthifolius & $15.72^{\mathrm{a}}$ & $3.13^{\mathrm{a}}$ & $13.30^{\mathrm{bc}}$ & $1.70^{\mathrm{c}}$ & 2.18 \\
& L.S.D & $10.28^{\mathrm{c}}$ & $1.31^{\mathrm{c}}$ & 1.39 \\
\hline
\end{tabular}

\section{N.S=not significant}

which presented and available for bees in Summer and Autumn.

\section{Chemical analysis of trapped pollen}

As seen from Table (5) there were variations in moisture levels of the analyzed types of the trapped pollen, where the highest level (16.39\%) of moisture was found with glass brush (Calistemon viminalis) pollen, while the lowest one $(13.66 \%)$ was detected with clover (Trifolium alexandrinum) pollen. Results indicated significant differences between moisture content of the different floral sources.

Results indicated that the crude lipids content of the trapped pollen detected in Calistemon viminalis pollen with the highest percentage of $(4.31 \%)$, followed by Phragmites australis (3.63\%), while the lowest percentage $(1.71 \%)$ was found in Trifolium alexandrinum pollen.

These results are not close to those results reported by Almedia et al. (2005) who found that pollen collected in Brazil had an average of $6 \%$ lipids and that might be to the variation between the floral sources of Brazil and Alexandria (El-sabheia region), Egypt.

Results in the same Table revealed that crude protein content ranged between 9.70 to $21.70 \%$. Calistemon viminalis pollen occupied the first rank (21.70\%), while Eucalyptus sp pollen recorded the last one $(9.70 \%)$. The current results not matched with those results reported by SaaOtero et al., (2000) who stated that protein content in the pollen of the individual taxa varied between $14.0 \%$ and $29.6 \%$, and (Almedia et al., 2005 ) founded that pollen had average of $20 \%$ protein. 
Determination of ash content of the studied pollen samples showed significant differences among the pollen types in the same table, Calistemon viminalis pollen possessed the highest content of ash (4.40\%), while Schinus terebinthifolius pollen recorded the lowest percentage $(1.31 \%)$ and there no significant differences between Eucalyptus, Phragmites australis and Schinus terebinthifolius of ash content. These results are somehow in agreement with Funari et al. (2003) who found that the ash content of the fresh pollen ranged between $2 \%$ and $6 \%$ and also Alemdia et al.(2005) who found that pollen had an average of $2.2 \%$ ash.

With concerning reducing sugars content, the obtained data revealed that the highest percentage (2.28\%) of reducing sugars was found with Eucalyptus sp pollen, followed by Phragmites australis $(2.18 \%)$, then Trifolium alexandrinum (1.96\%), while the lowest percentage $(1.39 \%)$ was detected in Schinus terebinthifolius pollen. There were no significant differences among the present type of flora.

These finding are not close to the results of Serra et al. (1986) who analyzed a total of 31 pollen samples, and found that percentages of reducing sugars in the tested pollen types ranged between 52 to $56 \%$.

Herein, our view point about these variations in literary information could be mainly attributed to a fact, that the followed chemical analysis was performed on the sampled pollen grains from different species of inspected growing plants of different geographical distribution, and prevailing environmental conditions in these geographical zones.

\section{REFERENCES}

A.O.A.C. 2000. Association of Official Analytical Chemists. Official Methods of Analysis 17 th Ed. A.O.A.C. International Washington D.C, USA.

Al-Ghamdi, A. A. 2002. The effect of pollen supplementary feeding on some activities of honey bee colonies during summer season in Riyadh, Saudi Arabia. Saudi J. Biol. Sci. 9:85-93.

Allen, M. D. and E. P. Jeffree 1956. The influence of stored pollen and of colony size on the brood rearing of honey bees. Ann. App. Biol., 44:649-656.

Almedia, L. B. , L. C. Pamplona, S. E. Coimbra and O. M. Brath 2005. Chemical composition and botanical evaluation of dried bee pollen pellets. J. Food composition analysis. 18(3): 105-111.

Al-Tikrity, W. S., R. C. Hillmann, A. W. Benton and W. W. Clarke 1971. A new instrument for brood measurement in a honeybee colony. Amer. Bee J. 111(4): 143 - 145.

Bell, R. R., E. J. Thornber, J. L. Seet, M. T. Groves, P. H. Nerissa and Bell, D. T. 1983. Composition and protein quality of honey bee collected pollen of Eucalyptus marginata and Eucalyptus calophylla. J. Nut. 113(12): 2479- 2484.

Bobrzecki, J. and J. Wilde 1991. The influence of pollen trapping by 3 types of pollen traps on the development and productivity of honey bee colonies. Pszczelinczezesz Novkowe. 35: 19-27.

COSTAT Software 1988. Microcomputer Program Analysis. Co-Hort software, Berkely, CA, USA.

Crailsheim, K., L. H. W. Schneider, N. Hrassnigg, G. Buhlmann, U. Brosch, R. Gmeinbauer and B. Schomann 1992. Pollen consumption and utilization in worker honey bees ( Apis mellifera carnica), dependence on individual age and function. J. insect Physiol. 38: 409-419.

De Groot, A. P. 1953. Protein and amino acid requirements of the honey bee ( Apis mellifera L.). Physiol. Comparate et d'Ecogia.3:195-285.

Doull, K. M. 1973. Relationship between pollen, brood rearing and consumption of pollen supplements by honey bees. Apidologie.4:285-293.

El-Shakaa, S. M. 1977. Studies on pollen grains collected by the honey bees in Giza region. M.Sc. Thesis, Fac. Agric., Cairo Univ., Egypt.

Ewies, M.A., M.S. Salem and M. Ali 1980. Brood rearing activity of the honey bee in relation to pollen gathering and some weather factors in Mostorod region. Zagazig Univ., Fac. Agric., Egypt. Research Bulletin.139 (5):1-10

Funari, S. R.C., H .C.Rocha, J. M. Sforcin, H. G. Filho, P. R. Curi, S. M. A. C. Dierckx, A. R.M. Funari and R.O. Oris 2003. Bromatological and mineral composition of collected for Africanized honey bees (Apis mellifera) in Botucatu, Sao Paulo State. Archivos Latinoamericanos de Produccion Animal. 11 (2): 87-93.

Gordon, E. A. and M. B. Diane 2002. Determination of Reducing Sugars with 3-Methyl-2benzothiazolinonehydrazone. Department of Food Science and Techno, Univ. , California, Davis, California 95616.

Hassan, A. R., H. M. Fathy, M. H. Bayoumy and Enas T. A. E. Tony 2015. Studies on activity of honeybee in collecting and storing pollen grains during spring and summer seasons. J. Plant Prot. Path., Mansoura Univ. 6 (2):255-268.

Hassona, Nadia M. 2006. Efficiency of the Italian honey bee queen Apis mellifera L. (Hymenoptera: Apidae) and its hybrids under the Egyptian environment. M.Sc. Thesis. Fac. Agric. (Saba Basha), Alex. Univ., Egypt.

Hellmich, R. L. and W. C. Rothenbuhler 1986. Relationship between different amounts of brood and the collection and use of pollen by the honey bee (Apis mellifera L.). Apidologie.17:13-20.

Ismail, A. M., A. A. Owayss, K. M. Mohanny and Rasha A. Salem 2013. Evaluation of pollen collected by honey bee, Apis mellifera L. colonies at Fayoum Governorate, Egypt. Part 1: Botanical origin. J. Saudi Soc. Agric. Sci. 12 (2): 129-135. 
Jevtic, G., M. Mladenovic, N. Nedic, D. Sokolovic and R. Strbanovic 2009. The correlation between colony strength, food supply and honey yield in honey bee colonies. Biot. Ani. Husb. 25:1141-1147.

Kaur, R. and N. R. Kumar 2013. Pollen foraging activity of Apis mellifera during autumn season in Chandigarh . HALTERES.4:12-14.

Khattab, M.M. 1976. Effect of ecological factors on honey bee activities. M.Sc. Thesis, Faculty of Agric., Cairo Univ.,Egypt.

Manning, R. 2001. Fatty acids in pollen : a review of their importance to honey bee. Bee world. 82:60-75.

Mishima, S., T. Miyata, K. M. Suzuki, Y. Araki, Y. Akao and Y. Isohama 2005. Estrogenic effects of royal jelly. J. Trad. Med. 22:171-175.

Roulston ,T. H., J. H. Cane and S. L. Buchmann 2000. What governs protein content of pollen: pollinator preferences, pollen -pistil interaction, or phylogeny?. Ecological Monographs. 70(4): 617-643.
Saa-Qtero, M. P., E. diaz - losada and E . F. Gomez 2000. Analysis of fatty acids, proteins and ethereal extract in honey bee pollen. Grana.39 (4):175-181.

Serra , B., J. Gonell - Golinde and A. Gomez - Pajvela 1986. Pollen collected by honeybee in Spain. J. Vida Apicola. 19: $35-38$.

Shokry, I. S. 1959. Studies in atmospheric pollen grains and fungus spores at Alexandria. Egypt. J. bot.2(1) 17-27.

Shoreirt, M. N., M. H. Hussein, M. O. M. Omar and M. F. Abdel-Rahman . 2002. Brood rearing of the honey bee colony individuals and their activities in Assiut region Egypt. J. Agric. Res. 80:83-104.

Somerville, D. 2000. Honey bee nutrition and supplementary feeding. AGNOTE, New Agic. DAI. 178:1-8.

Stanley, R. G. and H. F. Linskens . 1974. "Pollen: Biology, Biochemistry and Management."Springer-Verlag press. Berlin and New York. PP. 307.

Steel, R. G. D. and J. H. Torrie. 1981. Principles and procedures of statistic. A biometrical approach. $2^{\text {nd }}$ Ed. McGraw. Hill Kogahusha Ltd. PP. 633

\section{الملخص العربي}

\section{الأنواع الشائعة من حبوب اللقاح المجمعة بواسطة شغالات نحل العسل بمنطقة الصبحية،}

\section{محافظة الأسكندرية، مصر}

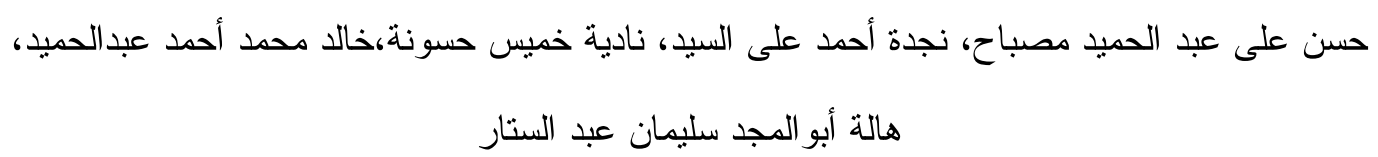

بالمصائد، بينما كان أقل مثوسط لهم كان فــى مــايو فــى الخلايا المعاملة بالمصائد و الغير معاملة.

أظهرت النتائج أيضا أن هنالك م مصادر نباتية مختلفــة

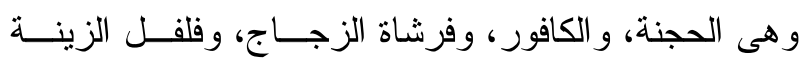
و البرسيم.

أوضح التحليل الكيميائى لحبوب اللقــاح المجمعــة أن فرشاة الزجاج هو الأعلى فـى نـسبة الرطوبـــة النـسبية و البروتين و الرماد و الدهون الكلية بينما كانت حبوب لقــاح الكافور هى الأعلى فى نسبة السكريات المختزلة و الأقل فى ولى

$$
\text { نسبة البروتين. }
$$

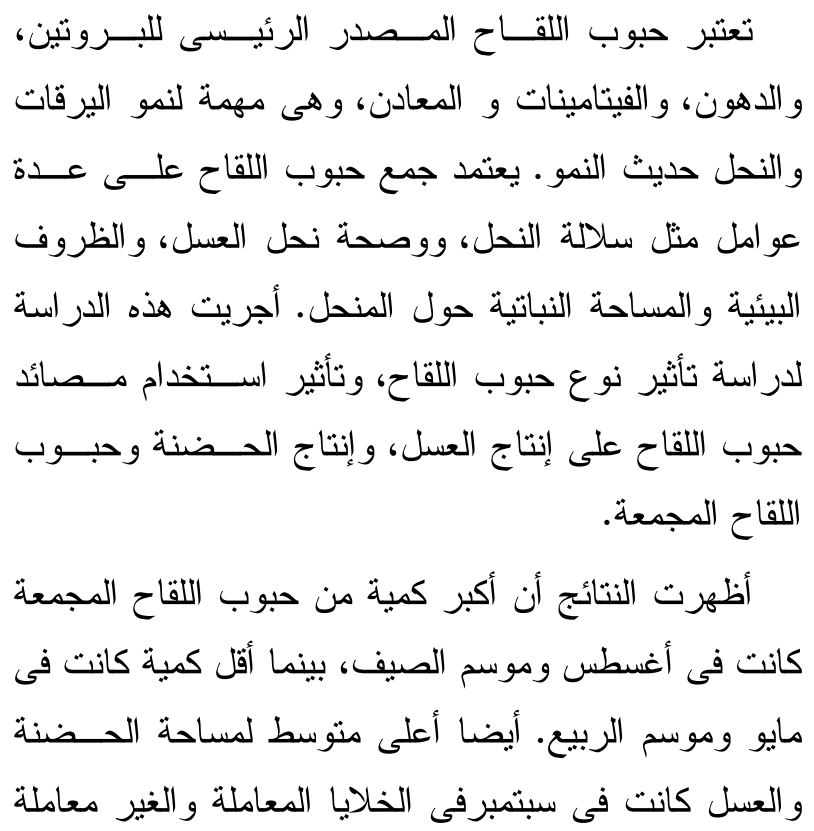

